Canadian University Music Review

Revue de musique des universités canadiennes

\title{
Andrew Thomson. Vincent d'Indy and His World. Oxford and New York: Clarendon Press, 1996. xv, 220 pp. ISBN 0-19-816220-0 (hardcover)
}

\section{Catrina Flint de Médicis}

Volume 20, numéro 2, 2000

URI : https://id.erudit.org/iderudit/1014467ar

DOI : https://doi.org/10.7202/1014467ar

Aller au sommaire du numéro

Éditeur(s)

Canadian University Music Society / Société de musique des universités canadiennes

ISSN

0710-0353 (imprimé)

2291-2436 (numérique)

Découvrir la revue

Citer ce compte rendu

de Médicis, C. F. (2000). Compte rendu de [Andrew Thomson. Vincent d'Indy and His World. Oxford and New York: Clarendon Press, 1996. xv, 220 pp. ISBN 0-19-816220-0 (hardcover)]. Canadian University Music Review / Revue de musique des universités canadiennes, 20(2), 125-128.

https://doi.org/10.7202/1014467ar

All Rights Reserved (c Canadian University Music Society / Société de musique des universités canadiennes, 2000
Ce document est protégé par la loi sur le droit d'auteur. L’utilisation des services d'Érudit (y compris la reproduction) est assujettie à sa politique d'utilisation que vous pouvez consulter en ligne.

https://apropos.erudit.org/fr/usagers/politique-dutilisation/ 
tention from its 'profound effect' when actualised in sound-as in the case of op. 11 and op. 21, although for different reasons" (p. 95). It is a measure of the persuasiveness of Rink's arguments that readers will hear these works anew, armed with a volley of fresh insights. A handbook such as this can only help chart the course, and the listener, not the reader, will ultimately decide whether these pieces warrant the resounding endorsement Rink gives them.

Glen Carruthers

Andrew Thomson. Vincent d'Indy and His World. Oxford and New York: Clarendon Press, 1996. xv, 220 pp. ISBN 0-19-816220-0 (hardcover).

Should the Marlborough Man ever be in need of a more elderly persona, the classic and often-reproduced photo of a smoking Vincent d'Indy might easily substitute. With his focused gaze, bushy mustache, tensed jaw, and upper lip firmly clamped down on a cigarette, d'Indy evokes all the clichés of the macho cowboy smoker, even though he may not be wearing the proper outfit. In his recent biographical survey of Vincent d'Indy, Andrew Thomson has included not only this classic photo of the composer, but one of him smoking hands free while reading a score, and another of him holding a cigarette in a pastoral setting. Thomson's biography probably does not contain every picture ever taken of d'Indy smoking, nor is it a complete accounting of his life and work. To be fair, the author admits that the work is brief. Indeed, his stated purpose is not so much to tell all of d'Indy's story as to tell it in a different way. He wants to salvage d'Indy, known to have frequently expressed extreme right-wing political views, and portrayed by his earliest biographer, Léon Vallas, as emotionally frigid. Thomson feels that he will be able to do this using the evidence of the journal intime, which Vallas and other scholars were not able to consult.

Thomson's project is ambitious, but problematic. Its ambition lies in treating a highly complex subject: a man with many faces who lived during a time of enormous political, social, and cultural upheaval.Vincent d'Indy also espoused values and engaged in political activities that may be problematic if not distasteful from our current point of view. But unlike the case of Wagner, for instance, d'Indy's music has not become so entrenched in our institutions that his complicated life and convoluted ethical stances need to be reconciled with a continued fascination for his music. To the obvious question "what is the point of rehabilitating him?," Thomson answers, "My hope is that having put the underlying ideas and ideologies into historical perspective, his music will be listened to on its own, very considerable merits" (p.ix). Thomson wishes to prove to us that d'Indy was an important person in his time; that his aesthetic-often judged negatively today - was shared and approved of by others, that his political orientation was contemporaneously justifiable.

Thomson has made some assumptions here that I think should not be made so lightly. First, showing context might mitigate negative views of a person's behaviour and political ideology, but it will not necessarily lead to a more positive reception of his or her works. This seems to assume that we should only 
appreciate music written by composers whom we feel to be morally and ethically above reproach. Second, promoting an appreciation for a composer's works does not necessarily have to be the main goal of a biography. Composers, especially those who engaged in a wide range of activities such as d'Indy, can be shown to be historically significant even if their works did not strongly influence the development of the art. Third, many musicologists would argue that the merit of music cannot be judged in absolute terms. Given the current musicological climate, i.e., the high degree of influence from feminist, gay-lesbian, and literary-critical viewpoints on many areas of mainstream musicology, I have to wonder why any writer would feel the necessity to make his or her subject seem so morally above reproach and so compositionally worthy. This kind of academic insecurity seems lethal to any meaningful study of "lesser" and problematic figures.

Vincent d'Indy's status as a composer has been barely acknowledged by the musicological canon. For since the Second World War and the coronation of Claude Debussy as the father of "modern" music, musicology has not felt an overwhelming need to account for d'Indy's presence in the musical life of late nineteenth-and early twentieth-century Paris. This is in spite of the fact that he was a prominent and highly respected member of the musical community. His music was performed by most of the respected concert societies and three of his operas were staged at the Opéra. He was a founding member of the Société nationale de musique and wielded considerable influence in premiering a number of seminal chamber music works. A well-known conductor in France, d'Indy also toured most of Europe as well as Russia and America, performing concerts of French works to appreciative audiences. Today, he is perhaps most often remembered as a teacher who helped to found the Schola Cantorum, a school that proved to be a serious rival to the Conservatoire in the years preceding the First World War.

Aside from a few early twentieth-century writings by former students and admirers of d'Indy, secondary literature on the composer is scarce. For years, the d'Indy bible was Léon Vallas's two-volume biography (the first of which appeared in 1946). The alternative was a very perfunctory study by Norman Demuth (1951). The situation is complicated by availability of sources, access to which is closely controlled by the d'Indy family. During this decade, however, Jane Fulcher has published on topics that include d'Indy and his circle, and a newer book by Jean and Francine Maillard (1994) provides more information about the composer's activities with the Schola. Today younger scholars are increasingly showing interest in both d'Indy and topics in which he figures as a key player. Examples of this kind of work include a recent book by Michel Duchesneau, and dissertations by Manuella Schwartz,Brian Hart, and Michael Strasser. ${ }^{1}$

Enter Andrew Thomson's biography. It is essentially a chronological narra-

\footnotetext{
${ }^{1}$ Michel Duchesneau, L'avant-garde musicale et ses sociétés à Paris de 1871 à 1939 (Sprimont, Belgium: Mardaga, 1997); Manuela Schwartz, "Wagner-Rezeption und französische Oper des Fin de Siècle : Untersuchungen zu Vincent d'Indys Fervaal" (Ph.D. diss., Technische Universität, Berlin,
} 
tive of d'Indy's life and milieu with musical interpolations. The chapter titles are very descriptive but not always indicative of a major theme, and many chapters read more like pot-pourris of biographical data than cohesive units. Often the relevance of the biographical information to the musical work is not clearly shown and transitions between the "life" and "work" sections are often awkward or non-existent. It would almost have been better to treat the music and the biography in separate sections. Although this is a somewhat dated approach, it would have allowed the author to treat the works in larger groups, or within some kind of overarching argument.

The analysis of d'Indy's music would be better called "description," with little raison d'être except to persuade the reader of d'Indy's passion by heavily interlacing his text with purple adjectives. For instance, Thomson tries to explain away Istar's perceived lack of sensuality by saying that the work was too philosophical to be erotic. Often the author tries to ally a particular work with music, literature, or philosophical views that we now consider important. Thus the social relationships in Fervaal are interpreted as similar to those in Debussy's Pelléas et Mélisande, L'étranger becomes an influence on Debussy's La mer, moments in the symphonic Jour d'été à la montagne are compared to Mahler's music, and La légende de saint Christophe is praised as "spectacular grand opera." The same type of approach appears to direct the sections treating d'Indy's non-musical work. In the extensive section on d'Indy's Cours de composition musicale, Thomson goes to some effort to show the influence of positivist philosopher Auguste Comte.

Many of the aspects of d'Indy's personality that might offend, including his right-wing political affiliations with the Action française, are acknowledged by the author.We also learn about the associations, writings, and works that reveal the composer as anti-Semitic. The author leaves no wart unstudied. Readers will learn of the Schola students's reputation as compositionally sterile, dogmatic, and even religious fanatics as well as d'Indy's negative criticism of composers and works that were later considered important milestones for the "development" of music. What may sit ill with the reader is Thomson's attempt to exculpate aspects of d'Indy that some might find contemptible. In Thomson's view, d'Indy's military background precluded loyalty to Dreyfus. and his position was reinforced by other prominent intellectuals of the time, such as Maurice Barrès. This kind of reasoning seems somewhat naive, and akin to that timelessly adolescent excuse, "but everyone else is doing it!" Something that I found quite unacceptable was Thomson's adoption of what seemed to me an overly casual tone to discuss the more controversial aspects of d'Indy's ideology. For instance, he referred to comments that have been interpreted as bigoted and racist in d'Indy's inaugural address to the Schola in 1900 quite summarily as, "passing swipes at familiar pet hates-Jews, commercialization, and Protestantism"(p.120).

1995); Brian J. Hart, "The Symphony in Theory and Practice in France, 1900-1914" (Ph.D. diss., Indiana University, 1994); Michael C. Strasser, “Ars Gallica: The Société Nationale de Musique and Its Role in French Musical Life, 1871-1891” (Ph.D. diss., University of Illinois, 1998). 
In keeping with his stated goals, Thomson maintains some constant threads. These mainly aim at ridding d'Indy of his image as "coldly rational" and keeper of unsavoury political views. Other threads include the benefit of his strict upbringing by his grandmother which taught him to control his raging passion; his obsession with father figures; his sincere devotion to Catholicism; his military background. Unfortunately, some of these threads do not seem to fit the weave, as though Thomson were madly looking for evidence of them and embroidering them on the surface of the text where ever possible. In other words, they seem to have been worked in after the completion of the main text.

One problematically argued of these continuous themes is d'Indy's military background, temperament, and allegiances. At the beginning of the book Thomson allots three pages to a description of the composer's brief stint with the 105th battalion of the National Guard during the Franco-Prussian War. It appears as though d'Indy spent most of the war crouching behind a fortified wall, with a unit that had a reputation as an "unreliable armed rabble" (p.13). After his first and only military charge, d'Indy resigned his post and managed to avoid the conflicts of the Commune by a retreat to Valence. This experience is supposed to have engendered strong loyalties to the military, transmuted in an anti-Dreyfus stance at the turn of the century and hardened into ultraconservative attitudes that an "old soldier" who "never dies" (as he is referred to in the penultimate chapter) might be expected to hold.

The interpretation of d'Indy's military leanings and its effect on his political stances may appear valid. However, it may be difficult for many readers to forgive d'Indy, especially in context of what is known about other artists with military experience in turn-of-the-century France. We know that many artists and composers took part in the Franco-Prussian War, and many did not become anti-Dreyfusards or anti-Semites as did d'Indy. For example, Gabriel Fauré also participated in the Franco-Prussian War, and he could be best described as completely apolitical. Indeed, a close associate and former professor at the Schola, Albert Roussel had a much more extensive military career than d'Indy, and this did not cause him to maintain or promote extreme right-wing political views. Andrew Thomson ends his biography with an epilogue, in which he decries the reception of d'Indy since the Second World War. He defends the composer by saying that, "above all, he stood as the implacable enemy of cultural trivialization and rampant commercial values in the arts. The battles he fought are no less ours today" (p. 220). But are these really "our" battles-whomever "we" are? This last sentence betrays an ideological point of view from which Thomson has observed and evaluated sources, and ultimately spun out his story about Vincent d'Indy. This makes it likely that persons who do not share Thomson's aesthetic and ideology may derive less satisfaction from his book than those who do.

Catrina Flint de Médicis 